\title{
İçsel Güdülenme Envanteri Dilsel Eşdeğerlik, Güvenirlik ve Geçerlik Çalışması
}

\author{
Ayşem ÇALIŞKUR* \\ Ayşe DEMIRHAN**
}

\begin{abstract}
Özet
Bu araştırmanın amacı, Ryan'ın ilk kez 1982 yılında geliştirdiği İçsel Güdülenme Envanteri'nin (İGE) "Intrinsic Motivation Inventory (IMI)" Türkiye dilsel eşdeğerlik, güvenirlik ve geçerlik çalışmasını yapmaktır. Bu araştırmada veriler İstanbul'da bulunan iki ayrı üniversitenin farklı bölümlerinde öğrenim gören öğrencilerden $(\mathrm{N}=320)$ toplanmıştır. Araştırmada test-tekrar test çalışması için bu örneklemden 42 kişinin verilerinden yararlanılmıştır. $\mathrm{Bu}$ örneklemin dışında, araştırmanın ölçüt geçerliği çalışması için Kültür Üniversitesi öğrencisi 40 kişiye iki ayrı güdülenme envanteri uygulanmıştır. İçsel Güdülenme Envanteri (İGE) dilsel eşdeğerlik, güvenirlik ve geçerlik çalışmasında yöntem olarak Faktör Analizi ve Korelasyon uygulanmıştır. Araştırma, öncelikle dilsel eşdeğerlik çalışmasıyla başlamıştır. Araştırmanın güvenirlik çalışmasında, envanterin test-tekrar test uygulaması yapılmıştır. Aynı ölçeğin iki farklı zamanda uygulaması arasında fark olup olmadığ Örneklemler İçin t-test" ile ölçülmüştür. İGE'nin test-tekrar test güvenirlik katsayısı hesaplanmış ve anlamlı ilişki görülmüştür. Faktör analizinde de anlamlı değerler elde edilmiştir. İGE'nin yapı geçerliğinin bir başka boyutu olan iç tutarlılık analizinde, ölçeğin alt ölçek ve toplamı arasında pozitif yönde anlamlı ilişkiler bulunmuştur. İGE'nin geçerlik çalışmasında son olarak, ölçüt geçerliği analizinde anlamlı ilişki elde edilmiştir. İGE dilsel eşdeğerlik, güvenirlik ve geçerlik çalışması sonucunda içsel güdülenme boyutlarını ölçebilmektedir.
\end{abstract}

Anahtar Sözcükler: İçsel Güdülenme Envanteri, dilsel eşdeğerlik, güvenirlik, geçerlik.

*Yrd.Doç.Dr. Ayşem ÇALIŞKUR, İstanbul Kültür Üniversitesi Psikoloji Bölümü

**Ar.Gör.Dr. Ayşe DEMİRHAN, Yıldız Teknik Üniversitesi İşletme Bölümü 


\title{
Intrinsic Motivation Inventory Linguistic Equivalence, Reliability and Validity Study
}

\begin{abstract}
The purpose of this study is to implement the linguistic equivalence, reliability and validity study of the Turkish version of the Intrinsic Motivation Inventory (IMI) "İçsel Güdülenme Envanteri (IGE)" developed by Ryan for the first time in 1982. In this research, data $(\mathrm{N}=320)$ has been collected from undergraduate students from different departments of two universities in Istanbul. In this research, for test-retest study has been conducted with 42 person from this sample. Other than this sample, the inventory has been applied to 40 university students in Kültür University were used for criterion validity. Factor Analyses and Correlation method were applied in accordance with the linguistic equivalence, reliability and validity study of the (IGE). In the first stage, began with the study of linguistic equivalence. In the reliability study, the same test was given to the same groups of students at two different times in order to determine the test-rest reliability of the "Paired Samples t-test" for the inventory was applied in order to determine whether there is any difference between two separate applications or not. Test-retest reliability coefficents of the IGE were calculated and it was found that there were significant correlations. In the Factor Analyses significant values were obtained too. In another dimension of construct validity (Internal Consistency Analyses) it was found that there were positive, significant correlations sub-test and total test. Finally, it was obtained that there was a significant correlation in the criterion validity analyse. IGE can measure the intrinsic motivation dimensions according to the results of the linguistic equivalence, reliability and validity study.
\end{abstract}

Keywords: Intrinsic Motivation Inventory, linguistic equivalence, reliability, validity.

\section{Giriş}

Güdülenme; insan psikolojisini anlamada yararlanılan anahtar kavramlardan biridir. Güdülenme; bugüne kadar farklı kuramlar ışığında ele alınarak incelenmiş, giderek güdülenmenin farklı alt türleri de hayatın farklı aşama ve süreçlerinde ele alınmış, sonuçta "İçsel Güdülenme" kavramı gelişmiştir. Endüstride özellikle 
iş hayatında çalışanların nasıl güdülendikleri üzerine araştırmalar artmaktadir.

Mccullagh'a göre (2005) "güdülenme, bir çabaya yoğunlaşma ve çabaya yönelik olmak" demektir. Yoğunlaşma, çabanın niceliğini ifade eder; çabaya yönelik olma ise ne yöne çekildiğinizi gösterir. Pinder'e göre (1998) "güdülenme, faaliyete sevk eden enerji verici güç" olarak tanımlanmaktadır. Güdülenme, görev veya faaliyete yönelik gayretin ne zaman, niçin ve nasıl dağıtılacağını bilinçli veya bilinçdışı olarak karar vermeyle ilişkilidir. Mccullagh (2005) ve Wilson'a göre (2005) yüksek güdülenme öğrenme, performans, hoşnutluk, sporda sebat gibi olumlu sonuçlarına işaret etmektedir. Ryan ve Deci'ye göre (2000) güdülenme, bir şey tarafından harekete geçirilme anlamını taşımaktadır. Bir kişi hareket etmeye yönelik bir uyaran veya ilham hissetmezse güdülenmemiş olarak kabul edilir, bunun tersine bir sonuca yönelik enerjik ve aktif hissediyorsa güdülenmiş olarak düşünülür. Pek çoğumuz diğerleriyle çalışır, bir arada hareket eder; bu faaliyetler ister bir başkasına, ister kendimize, isterse bir göreve yönelik olsun güdülenmenin miktarının ne olduğu sorusu akla gelmektedir -ki güdülenme miktarı azdan çoğa doğru çeşitlenebilmektedir. Ayrıca güdülenmenin yönelimi de söz konusudur -ki kişiyi harekete geçiren güdülenme durumunun ilişkili olduğu tutum ve hedefler faaliyetin nedenini ortaya koyar. Pek çok kuram güdülenmeyi bu ilişkiler bağlamında açıklamakta ve güdülenmeyi bir bütün olarak ele almaktadır.

İş güdülenmesi Mitcell'e göre (1997) “İşteki hedeflere yönelik gönüllü faaliyetlerin uyanması, yönetimi, yoğunluğu ve sürekliğine dair psikolojik süreçler"i ifade etmektedir. Nelson ve Quick'e göre iş güdülenmesi (2000), "Amaç yönelimli davranışın meydana gelmesi ve sürdürme süreci, bir kişinin veya örgütün davranışını etkileyen görece sabit özellikler grubu"dur. Franco, Bennett ve Kanfer (2002) iş güdülenmesini, "Örgütsel hedeflere yönelik çabayı sarfedip sürdürmeye dair bireysel gönüllülük düzeyi" olarak tanımlamışlardır. Karatepe ve Uludağ iş güdülenmesinin (2007) işle ilgili ve tutumla ilgili çıktılar bakımından güçlü bir etkiye sahip önemli bir fenomen olduğunu belirtmektedir. Yıldız, Ayhan ve Erdoğmuş'a göre (2009) iş güdülenmesine sahip çalışanlar daha düşük düzeyde işten ayrılma niyeti göstermektedir.

İnsan fizyolojik ve psikolojik olarak gelişen bir varlık olarak ele alan kuramcılar iş güdülenmesiyle ilgili olarak kişinin içsel yetenekleri, kapasitesi, bilişsel ve duygusal yönleri üzerinde durmaktadır ve kişiyi bu etmenler doğrultusunda güdülemeye 
çalışmaktadır -ki bu grup yaklaşım "Kapsam Kuramları" olarak adlandırılır. Diğer kuramcılar ise kişiyi etkileyen dışsal etmenlerin iş güdülenmesinde belirleyici olduğunu öne sürmektedirler; bu grup yaklaşım ise "Süreç Kuramları" olarak adlandırılır (Koçel, 2007).

Kapsam Kuramları Maslow'ın İhtiyaçlar Hiyeraşisi, Herzberg'in Çift Etmen Kuramı ve Mc Clelland'ın Başarma İhtiyacı Kuramı ve Alderfer'in ERG Yaklaşımıdır. Süreç Kuramları ise Koşullanma İlkeleri doğrultusunda Skinner ve Thorndike gibi bilim insanları tarafından geliştirilen Davranış Koşullama'nın iş hayatındaki uygulaması, Vroom'un Bekleyiş Kuramı, ve LawlerPorter'ın bu kurama eklemeleriyle oluşan Güdülenme Kuramı, Adams'ın Eşitlik Kuramı ve Locke tarafından geliştirilen Amaç Kuramı'dır (Koçel, 2007).

İş güdülenmesiyle ilgili olarak kişinin içsel nedenselliğini ön plana alan yaklaşımlar içsel güdülenmeyi vurgulamakta, dışsal nedenselliği ön plana alan yaklaşımlar ise dışsal güdülenmeyi vurgulamaktadir.

İçsel güdülenme kavramı, kişinin benliğinin kendiliğinden ve aktif doğasını betimlemek üzere Harlow ve Meyer (1950) tarafından dile getirilmiştir. Daha sonra içsel güdülenme kavramsal bir ifade olarak, White (1959) tarafından ele alınmış ve içsel güdülenmenin sadece güdülenmenin etkinliğine yakın bir kavram değil, aynı zamanda Hartmann gibi Psikanalitik Ego Psikologlarının öne sürdüğü "bağımsız ego enerjisi" kavramına da benzer olduğu ifade edilmiştir. White; Murray'ın (1938) yaptığı mülakat analizlerinde bir varsayım olarak geliştirdiği "psikolojik (dürtüsel olmayan) ihtiyaç" kavramının izini sürmüş ve "uzmanlık için içsel ihtiyaç" varsayımına dayanarak içsel güdülenme kavramını literatüre yerleştirmiştir. White'a göre insan organizması çevreyle başa çıkmak üzere doğal olarak etkin olmaya güdülenmektedir; uzmanlık (etkinlik) duygusu çevreyle uzman etkileşimlerin bir sonucudur ve bu tip davranışlar için bir ödüldür -ki bu ödül dürtü temelli pekiştireçlerin dışında kalarak süregider. İçsel güdülenme, 1950'li ve 1960'lı yıllarda iki baskın davranış̧̧ı kuram olan Skinner'ın Edimsel Koşullanma Kuramı ve Hull'ın Dürtü Kuramı'na karşı geliştirilen bir kavram olarak literatürde yer almıştır. Skinner (1953), tüm davranışların yemek ve para gibi ayrılabilir ödüllerle güdülendiğini öne sürmüştür, içsel olarak güdülenen faaliyetler için ise faaliyetin kendisini bir ödül olarak görmüştür. Hull ise (1943) tüm davranışların fizyolojik dürtüler ve onların türevleriyle oluştuğunu; içsel olarak güdülenen 
faaliyetin ise doğal psikolojik ihtiyaçlardan biri olan onaylanmış başarıya karşıllk geldiğini öne sürmüştür.

Deci ve Ryan; temel, evrensel olan psikolojik ihtiyaçları, edinilmiş güdülerden ayrı tutarak doğuştan getirilen gereklilikler olarak ele almakta ve 3 psikolojik ihtiyaç tanımlamaktadır: Uzmanlık ihtiyacı; kişilerin sonuçları denetleme çabası ve etkin olma deneyimi, diğer bir deyişle kişiyi arzulanan sonuçlara götürecek araçsallıkları anlama ve bunlar üzerinde güvenilir bir etkiye sahip olabilmektir. Özerklik ihtiyacı; kişinin davranışlarında kendisini orijinal kaynak gibi hissetmesi ve kendi davranışlarını belirlemede kendine ait bir sese veya girdiye dayanmasıdır -ki bu, kişinin davranış açısından içsel nedensellik algısı deneyimini arzulamasıdır (kişinin kendi benliğinden doğan şekilde davranma deneyimi). İlişki kurma ihtiyacı da, kişinin diğer insanlarla bağlantı kurması, sevme ve sevilme, grup aidiyeti, toplumun bir üyesi olma ihtiyacıdır -ki içselleştirmenin etkin şekilde gerçekleşmesi için çok önemlidir. Bu psikolojik ihtiyaçların başarı ile karşılanması halinde içsel güdülenme ve içselleştirme gerçekleşir (Ryan ve Deci, 2000).

Deci ve Ryan (1985) farklı güdülenme türlerini, hareketi uyandıran farklı nedenler ve hedefler temelinde açıklamaktadır. Bu bağlamda, en önemli ayrım içsel güdülenme ve dışsal güdülenme kavramları arasındadır. İçsel güdülenme; bir şeyi özünde ilginç ve zevkli bulduğu için yapmaktır; dişsal güdülenme ise bir şeyi ayrılabilir bir sonuca bağlı olarak yapmaktır. İçsel güdülenmenin işaret ettiği temel bilgi, gönüllü bir davranışın tümden edimsel pekiştirmeye bağlı olmadığı ve yine pekiştirmeden bağımsız davranışın, bir hata silsilesinden türemediğidir; gönüllü davranışların, hayatın içinde kendiliğinden oluşan duygu ve bilişlere karşılık gelen ödüllendirici sonuçlara gereksinim duyduğu belirtilmiştir. İçsel güdülenmeye dair ödüllendirici sonucun, sıkça "faaliyetin kendisinde" olduğu belirtilmiştir ancak bu çerçeve içsel ödülü dışsal ödül kavramından yeterince ayırt edici değildir; Berlyne (1971) içsel ödülün faaliyette değil "insanın içinde" olduğunu belirtmiştir. Deci ve Ryan'a göre, içsel ödüllendirici sonuçlar bir faaliyete eşlik eden kişilerin yaşadığı, kendiliğinden oluşan duygu ve düşüncelerdir. (akt.Deci ve Ryan, 1991). Thomas'a göre (2000) içsel güdülenmenin psikolojik işaretleri, anlamlılık hissi, seçim, uzmanlık ve ilerlemedir.

İçsel ve dışsal güdülenme ile ilgili yapılan araştırmalarda iş hayatında güdülenme ile çeşitli değişkenlerin ilişkili olduğu görülmektedir. Mottaz (1985), içsel ve dışsal güdülenmenin iş 
doyumu üzerindeki etkisini ele aldıkları çalışmasında, içsel ödüllerin iş doyumu üzerinde işletmedeki tüm gruplarda en güçlü etkiye sahip gösterge olduğunu belirtmiştir. İçsel güdülenmenin daha yüksek statülü işlerde düşük statülü işlere göre ön plana çıktığını; ayrıca uzun süredir o işletmede çalışanlar arasında artma eğilimi gösterdiğini saptamıştır. Karatepe ve Uludağ'a göre (2007) bazı araştırmalarda içsel güdülenmenin; düşük düzeyde tükenmişliğe, artan iş doyumuna ve yüksek düzeyde örgütsel bağlılığa eşlik ettiği görülmektedir. Dündar ve arkadaşları (2007) işsel ve dışsal güdülenme araçlarının çalışanlar üzerindeki etkisini karşılaştırdıkları çalışmalarında, içsel güdülenme araçlarının dışsal güdülenme araçlarına göre daha etkili olduğunu tespit etmişlerdir. Ağca ve Ertan'ın (2008), otel işletmelerinde çalışanların örgütsel bağlılık ve işe yönelik içsel güdülenme ilişkisini inceleyen araştırmalarında örgütsel bağlılık ile içsel güdülenme arasında anlamlı bir ilişki saptanmıştır. Kuruüzüm ve arkadaşlarının (2010) araştırmasında, imalat ve hizmet sektöründe çalışanların içsel güdülenme, iş değerleri ve kontrol odağ ile işe bağlılık arasında anlamlı ilişki elde etmiştir. Özellikle hizmet sektöründe işe bağlllı̆̆ en çok etkileyen değişkenlerin içsel güdülenme ve iş değerleri olduğu saptanmıştır. Olusola (2011), işçilerin içsel güdülenme ve iş performansını incelediği araştırmasında içsel güdülenme ile iş performansı arasında anlamlı ilişki elde etmiştir. Huddlestone ve arkadaşları (2012) çalışanlarda algılanan güdüsel iklim ile içsel güdülenme arasında anlamlı ilişki elde etmişlerdir.

İçsel güdülenme envanterleri incelendiğinde, bunlardan biri Mottaz'ın (1981) yılında geliştirdiği “Intrinsic Task Rewards" adlı; görevin özerkliği, görevin anlamlılığı ve göreve bağlılık boyutlarının yer aldığı Likert tipi ölçektir. Bu ölçeğin güvenirlik katsayısı; görev özerkliği boyutu için 0.917, görevin anlamlılığ 1 boyutu için 0.790 , göreve bağlılık boyutu içinse 0.875 olarak elde edilmiştir. Ayrıca geçerlik için faktör analizi yapılmış ve faktör gruplarının ayrı boyutlara yeterli düzeyde dağıldığı görülmüştür. (Mottaz, 1985).

İçsel güdülenme envanterlerinin bir diğeri Mayo'nun 1976 yılında geliştirdiği Task Reaction Questionnaire (TRQ)'dur. Ölçek 7'li Likert tipidir; içsel tutarlılığı 0.93 ile 0.95 değerleri arasındadır. İki yarım güvenirliği değeri 0.96 olarak elde edilmiştir; ancak ölçeğin faktör yapısıyla ilgili bir bulgu sunulmamıştır.

Amabile ve arkadaşları (1994) tarafından geliştirilen Work Preference Inventory (WPI) içsel ve dişsal güdülenmeyi bir arada ölçen ölçeklerden biridir. 30 maddeden oluşan ölçeğin içsel 
güdülenmeyi ölçen iki alt boyutu bulunmaktadır: İlgi duyma/Hoşlanma ve meydan okuma. Ölçeğin orijinalinin İçsel Güdülenme alt boyutu için güvenirlik Cronbach Alfa değeri 0.75, Dişsal Güdülenme alt boyutu içinse 0.70 olarak bulunmuştur.

Gagne ve arkadaşlarının 2007 yılında geliştirdiği iş güdülenme ölçeği Motivation At Work Scale (MAWS), ÖzBelirleyicilik Kuramı temel alınarak 4 ayrı boyutu içsel güdülenme, özdeşleşme, içeatım ve dışsal düzenleme boyutlarını içeren bir ölçektir. Bu ölçek, İngilizce ve Fransızca olarak hazırlanmış ve İngiliz ve Fransız denek gruplarından ayrı ayrı güvenirlik ve geçerlik puanları elde edilmiştir. Güvenirlik çalışmasında değerler $\alpha=0.75$ ile 0.91 arasında yer almıştır. Yapılan faktör analizinde 4 boyutun da en iyi temsili sağladığı görülmüştür ve faktör yükleri 0.61 ile 0.95 değerleri arasındadır (Gagne ve ark., 2008).

Guay, Vallerand ve Blanchard'ın (2000) geliştirdiği Situational Motivation Scale (SIMS) içsel ve dışsal güdülenmeyi ölçme amacını taşımaktadır. 26 maddeden oluşan ölçek 7'li Likert tipidir ve 4 alt ölçekten oluşmaktadır. Güvenirlik çalışmasında Cronbach's $\alpha=0.89$ olarak elde edilmiştir; içsel tutarlılık değerleri ise Cronbach's $\alpha=0.77$ ile 0.95 arasında dağılmaktadır. Yapı geçerliği çalışmasında katsayı 0.71 olarak elde edilmiştir. Ölçeğin alt ölçekleri arasında $p<0.01$ düzeyinde anlamlı ilişkiler elde edilmiştir: ayrıca geçerlik çalışmasında bir başka güdülenme ölçeği olan Academic Motivation Scale'in alt ölçekleriyle SIMS'ın alt ölçekleri arasındaki korelasyon değerleri bazı alt ölçekler için $p<0.05$ ve $p<0.01$ düzeyinde anlamlıdır. Ayrıca Guay ve Vallerand'ın 2003 yılında geliştirdiği Global Motivation Scale (GMS); 3 alt boyutta içsel güdülenme, dişsal güdülenme ve güdülenmesiz durumu ölçen, 28 maddeden oluşan 7 'li Likert tipi bir ölçektir. İçsel güdülenme 12 madde ile ölçülmektedir. Ölçeğin görece sosyal beğenirlikten bağımsız olarak güvenilir ve geçerli olduğu belirtilmiştir (Guay, Mageau ve Vallerand, 2003).

İGE dilsel eşdeğerlik, güvenirlik ve geçerlik çalışmasının amacl; İGE'nin Türkiye'de uygulanabilirliğini belirlemeye yönelik olarak dilsel eşdeğerlik, geçerlilik ve güvenilirlik çalışmasının yapilmasidir.

$\mathrm{Bu}$ araştırmanın önemi; farklı meslek gruplarına yönelik olarak eğitim alan veya çalışan kişilerin içsel güdülenme açısından farkındalık kazanmaları, gençlerin ileriki yaşamlarında başarılı olabilmek için içsel güdülenme kaynaklarının önemli bir unsur olduğunu bilerek bilinçli tercihler yapabilmeleri ve halihazırda 
çalışanların içsel güdülenme durumlarını belirlemek üzere yeterli bir ölçek sunabilmektir.

Araştırmanın amacı; İGE'nin Türkiye koşullarına göre dilsel eşdeğerliği, güvenirlik ve geçerlik düzeylerinin belirlenmesidir.

\section{Yöntem}

Araştırmanın yöntemi İGE'nin İngilizce orijinal metninin (IMI) dilsel eşdeğerlik çalışması ile güvenirlik ve geçerlik çalışmasından oluşmaktadır. Ölçeğin güvenirlik ve geçerlik ölçümlerinde korelasyon ve faktör analizi yöntemi uygulanmıştır. Araştırmanın örneklemi, temsil edicilik özelliğini güçlendirmek üzere bir vakıf ve bir devlet üniversitesindeki farklı bölümlerde öğrenim gören öğrencilerden gönüllülük esasına göre seçilmiştir. Araştırma örneklemine girecek kişi sayısı, "kolayda örnekleme (convenience sampling)" formülü kullanılarak \%5 hata payı ile en az 192 olarak hesaplanmıştır (Orhunbilge, 2000). Araştırma konusuyla ilgili olan ve doğru yerde, doğru zamanda bulunan birimler arasından keyfi olarak birimler seçiliyorsa yapılan örneklemeye "kolayda örnekleme" denir. Kolayda örnekleme gönüllülük esasına göre katılan birimlerden oluşur (Özmen, A., 2013).

\section{Evren ve Örneklem}

$\mathrm{Bu}$ araştırmanın evrenini İstanbul ilinde bulunan 3 üniversitedeki üniversite öğrencileri oluşturmaktadır. Araştırmanın örneklemini, biri devlet diğeri özel olmak üzere iki üniversitede (Yıldız Teknik Üniversitesi ve İstanbul Arel Üniversitesi) eğitim gören öğrenciler oluşturmuştur $(\mathrm{N}=320)$. Araştırmaya bu ana örneklemin dışında ölçüt geçerliği çalışmasını yapmak üzere Kültür Üniversitesi Psikoloji Bölümü öğrencilerinden 40 kişi daha (aynı öğrencilere tekrar ulaşabilme koşulu nedeniyle) dahil edilmiştir. Araştırmaya katılan öğrencilerin bölümleri; İşletme, İktisat, Siyaset bilimi ve Uluslararası İlişkiler, Psikoloji, Sosyoloji, Gazetecilik, Halkla İlişkiler ve Reklamcılık, İç mimarlık, Türk Dili ve Edebiyatı, Matematik-Bilgisayar, Elektrik-Elektronik Mühendisliği ile Turizm ve Otelcilik'tir. Araştırmanın genelinde toplam 320 kişiden veri toplanmıştır. Araştırmanın ölçüt geçerliği çalışmasında ise Kültür Üniversitesi Psikoloji Bölümü öğrencilerinden 40 kişiye ayrıca uygulama yapılmıştır. Araştırma sonucunda elde edilen veriler, SPSS 18.0 istatistik programı ile değerlendirilmiştir.

\section{Veri Toplama Aracı}


Araştırmanın güvenirlik ve geçerlik çalışmasının yapıldığı İGE (orijinali IMI) Ryan ve meslekdaşlarının Rochester Güdülenme Araştırma Grubu içinde başlayan, kişilerin güdü deneyimleri ve deneysel görevlerine göre çok boyutlu güdü düzeylerini ölçmeyi amaçlayan bir envanterdir. IMI, Ryan tarafından 1982 yılında geliştirilmiştir. Bu envanterin odaklandığı görev/meslek bağlamına göre değişen 5 ayrı tipi olup ölçeğin maddeleri de farklılaşmaktadır; envanter ile ilgili bilgilerde araştırmacıların amaçlarına uygun olarak envanterin farklı versiyonlarını kullanabilecekleri ve hatta versiyonlar arasında sadece gerekli gördükleri alt ölçeklerden yararlanabilecekleri belirtilmiştir. İGE, kişilerin öz değerlendirmelerine dayalıdır, yani kişiler kendi güdülenme durumlarını değerlendirmektedirler. Envanterin güvenirlik ve geçerlik çalışması McAuley, Duncan ve Tammen tarafından yapılmıştır; envanterin orijinalinin güvenirlik katsayısı alt ölçeklere göre $\alpha=0.68$ ile 0.84 arasındadır. Envanterin bütününün iç tutarlık katsayısı ise $\alpha=0.85^{\prime}$ tir. Envanterin orijinalinin faktör analizinde ise, 4 temel faktör grubuna (İlgi Duyma/Hoşlanma, Algılanan Yeterlik, Çaba/Önem, Baskı/Gerilim) karşılık gelen 18 madde belirlenmiştir. 4 faktör grubuna dağılan envanterin 18 maddelik ve 16 maddelik versiyonları karşılaştırılmış ve orta düzeyde ilişkili bulunmuştur. Ayrıca bu iki ayrı versiyonun Ki-Kare değerleri ölçeğin $p<0.05$ düzeyinde anlamlı olduğunu ve ölçeğin geçerli olduğunu göstermektedir. (McAuley, Duncan ve Tammen, 1989).

İGE'nin orijinali IMI, içsel güdülenmenin ölçüldüğü çeşitli araştırmalarda kullanılmıştır. Amorose (2001), spor koleji öğrencilerinin koçlarının davranışları ile içsel güdülenmesi arasındaki ilişkiyi ele aldığı çalışmada IMI'den yararlanmışlardır. Murcia ve arkadaşları (2012), öğrencilerin sosyal hedefleri, temel psikolojik ihtiyaçları ve içsel güdülenmelerini ele aldıkları araştırmalarında IMI'yi ölçek olarak kullanmışlardır. Viira ve Koka (2012), öğrencilerin algıladıkları destek ihtiyacı, başarı ihtiyacı ve içsel güdülenme ilişkisini ele aldıkları araştırmada IMI'nin "Algılanan Yeterlik" boyutu sorularını ölçek olarak kullanmışlardır. Olusola (2011), işçilerin içsel güdülenme ve iş performansını incelediği araştırmasında IMI'den yararlanmıştır. Huddleston ve arkadaşları (2012) IMI'yi bir işletmedeki çalışanların algıladıkları güdüsel iklim ile içsel güdülenmelerini araştırdıkları çalışmalarında kullanmışlardır.

İGE'nin güvenirlik ve geçerlik çalışmalarının yapıldığı orijinal ölçek 6 alt ölçekten oluşan İlgi Duyma/Hoşlanma, Algglanan Yeterlik, Çaba/Önem, Baskı/Gerilim, Alģlanan Seçme Hakkı ve Değer/Fayda'yı içeren ve çalışanların içsel güdülenme düzeylerini ölçmeye yönelik 
olan -orijinali 45 maddeden oluşan ancak bu araştırmanın kapsamı dahilinde gerekli olan alt ölçekler esas alındığından- 37 maddelik 7'li Likert tipi bir envanterdir. Ancak orijinal envanterdeki 3 madde, açık uçlu soru olduğundan ve araştırma nicel yöntemle yürütülmek istendiğinden bu araştırmaya dahil edilmeyip 34 madde halinde hazırlanmıştır. İGE'deki ifadelere, demografik niteliklere ait (yaş, cinsiyet, sınıf ve bölüm) sorular dahil edilerek anket formu hazırlanmıştır (Ek 1).

İGE, iş güdülenmesini içsel güdülenme bağlamında ölçmeyi hedefleyen bir öz değerlendirme envanteridir. Bununla birlikte envanter, dilsel eşdeğerlik, güvenirlik ve geçerlik aşamasında öğrencilere uygulanmıştır. Envanterin uygulanması sırasında, öğrencilere derslerinin genelini ve gelecekteki mesleklerini düşünerek envanterdeki güdülenme ifadelerini değerlendirmeleri özellikle rica edilmiştir. Envanterin uygulama süresi 10-15 dakika olup, bir gözetmen eşliğinde bireysel veya grup testi olarak çalışanlara veya iş hayatına hazırlananlara uygulanabilmektedir.

\section{Veri Analizi}

İGE'nin dilsel eşdeğerlik çalışması, güvenirlik ve geçerlik çalışmasının ilk aşamasını oluşturmaktadır. Envanterin orijinal 37 maddelik İngilizce metnini İngiliz Dili ve Edebiyatı Bölümü'nde görevli 1 öğretim üyesi ve Psikoloji Bölümü'nde görevli 3 öğretim üyesi ayrı ayrı incelemiş, ölçek metni önce İngilizce'den Türkçe'ye sonra Türkçe'den İngilizce'ye ardından tekrar İngilizce'den Türkçe'ye çevrilerek karşılaştırılmış, çevirisinde sorun yaşanan sözcük ve cümleler tekrar ele alınmıştır. İGE dilsel eşdeğerlik çalışmasında, bazı sözcük ve cümleler Türk kültür yapısına uygun, orijinal ölçeğin hedeflediği anlamı verecek biçimde yeniden düzenlenmiştir. Bu çalışma sonucunda İGE Türkçe formunun son halini almıştır.

İGE'nin test-tekrar test güvenirliğini ölçmek amaciyla, 2 hafta arayla aynı öğrenci gruplarına (toplam 42 kişi) uygulanmış ve iki uygulama arasında fark olup olmadığını belirlemek üzere "bağımlı örnekler t-test" yapılmıştır. Ayrıca test-tekrar test korelasyon katsayısı hesaplanmıştır.

İGE'nin geçerlik çalışmasında öncelikle envanterin yapı geçerliğini belirlemek için faktör analizi yapılmış ve alt boyutun Cronbach Alpha değerleri hesaplanmıştır. Envanterin yapı geçerliğinin bir başka boyutu olan iç tutarlılığını belirlemek için; ölçeğin alt ölçek ve toplam ölçek korelasyonları hesaplanmıştır. Ayrıca envanterin ölçüt geçerliğini saptamak için katılımcılara IMI ile 
Uşak Üniversitesi Sosyal Bilimler Dergisi

A. ÇALIŞKUR, A. DEMIRHAN

Mottaz'ın (1985) geliştirdiği, Dündar ve arkadaşlarının (2007) düzendiği "İçsel Motivasyon Anketi" (IMA) uygulanmıştır. Bu ölçeklere ölçüt geçerliğini saptayacak istatistiksel analizler yapılmıştır

\section{Bulgular}

Araştırmanın bu bölümünde demografik bulgular ile geçerlilik ve güvenilirlik analizi sonuçlarına yer verilecektir.

Araştırmada katılımcıların demografik özelliklerine ait genel bilgiler şöyledir: Araştırmanın örneklemi 320 katılımcıdan oluşmaktadır ( $\mathrm{N}=320)$. Araştırmaya katılanların 186'sı kadın ve 134'ü erkektir. Katılımcıların tümü öğrenci olup, toplamı 320 kişidir. Katılımcıların yaş dağılımı incelendiğinde, 295'i 18-21 yaş aralığında, 16'sı 22-25 yaş aralığında, 9'u 26-29 yaş aralığındadır. Katılımcıların 85'i 1.sınıf, 119'u 2.sınıf, 92'si 3.sınıf, 24'ü 4.sınıf öğrencisidir (Bakınız Tablo 1).

Tablo 1: Araștırma Katılımcılarının Demografik Özellikleri

\begin{tabular}{llcc}
\hline & & Frekans & $\%$ \\
\hline Cinsiyet & Kadın & 186 & 58.1 \\
& Erkek & 134 & 41.8 \\
\hline \multirow{3}{*}{ Yaş Grubu } & 18-21 yaş arası & 295 & 92.1 \\
& 22-25 yaş arası & 16 & 5.0 \\
& 26-29 yaş arası & 9 & 2.8 \\
\hline Sınıf & 1.sınıf & 85 & 26.5 \\
& 2.sınıf & 119 & 37.2 \\
& 3.sınıf & 92 & 28.7 \\
& 4.sınıf & 24 & 7.5 \\
\hline
\end{tabular}

Güvenirlik çalışmasında, İçsel Güdülenme Envanteri'nin iki ayrı uygulaması arasında fark olup olmadığını belirlemek ve testtekrar test güvenirliğini belirlemek üzere 42 kişiye İGE uygulanmış ve 2 hafta ara verildikten sonra aynı kişilere bu envanter tekrar uygulanmıştır. İki uygulamanın yanıt ortalamaları arasında fark olup olmadığının belirlenmesi için "bağımlı örnekler t- test" uygulanmıştır. Elde edilen sonuçlar Tablo 2'de sunulmuştur:

Tablo 2: İGE Alt Ölçek ve Toplam Puanlarmmn Test-Tekrar Test Güvenilirliği Bağımlı Örnek t-test Sonuçları

\begin{tabular}{llll}
\hline Madde & $\mathrm{n}$ & $\mathrm{t}$ & Anlamlilik(p) \\
\hline
\end{tabular}


Uşak Üniversitesi Sosyal Bilimler Dergisi

A. ÇALIŞKUR, A. DEMIRHAN

\begin{tabular}{llll}
\hline İlgi Duyma/Hoşlanma & 42 & 1.603 & 0.115 \\
Algılanan Yeterlik & 42 & 0.757 & 0.453 \\
Algılanan Seçme & 42 & 1.572 & 0.137 \\
Hakkı & 42 & 0.997 & 0.325 \\
Değer/Fayda & 42 & 0.183 & 0.856 \\
Çaba/Önem & 42 & 0.186 & 0.853 \\
Baski/Gerilim & 42 & 1.343 & 0.187 \\
İş Algisı & 42 & 1.474 & 0.158 \\
Toplam & & & \\
\hline
\end{tabular}

Tablo 2'de görüldüğü gibi p>0.05 olduğundan katılımcıların envantere vermiş oldukları yanıtlar arasında anlamlı bir farklılık olmadığ1 görülmüsştür. İGE alt ölçek ve toplam puanlarının test-tekrar test güvenilirliği "bağımlı örnekler t-test" ile araştırıldığında hem toplam, hem madde puanlarının zamana bağlı bir değişim göstermediği belirlenmiştir. $\mathrm{Bu}$ nedenle, ölçeğin çalışmada kullanılabileceği karar verilmiştir.

Pearson Korelasyon Analizi sonuçları da test-tekrar testi uygulamasından elde edilen alt ölçek ve toplam puanlarının pozitif yönde ve ileri düzeyde anlamlı ilişki gösterdiğini ortaya koymaktadır. Tablo 3'te görüldügü gibi, iki farklı zaman İGE toplam puanı ve alt ölçek puanları arasındaki ilişki katsayılarının r=0.608 (Algılanan Seçme Hakkı) ile r=0.910 (İlgi Duyma/Hoşlanma) arasında değiştiği ve $\mathrm{p}<0.01$ olduğu görülmektedir.

Tablo 3 : IGG'nin Test-Tekrar Test Alt Ölçek ve Toplam Puanlarn Arasındaki Korelasyon Değerleri

\begin{tabular}{lccc}
\hline Madde & $\mathrm{n}$ & Korelasyon(r) & Anlamlllı(p) \\
\hline İlgi Duyma/Hoşlanma & 42 & 0.910 & 0.000 \\
Algılanan Yeterlik & 42 & 0.782 & 0.000 \\
Algılanan Seçme Hakkı & 42 & 0.608 & 0.000 \\
Değer/Fayda & 42 & 0.790 & 0.000 \\
Çaba/Önem & 42 & 0.693 & 0.004 \\
Baskı/Gerilim & 42 & 0.642 & 0.000 \\
İş Alg1sı & 42 & 0.839 & 0.000 \\
Toplam & 42 & 0.838 & 0.000 \\
\hline
\end{tabular}

Geçerlik çalışmasında öncelikle; İGE'nin yapı geçerliğini belirlenmeye çalışılmıştır. İGE'yi oluşturan 34 sorunun alt boyutlarını belirleyebilmek ve yapı geçerliliğini ortaya çıkarabilmek amacıyla Faktör Analizi gerçekleştirilmiştir. Envanterin orijinalinde 34 soru; İlgi 
Uşak Üniversitesi Sosyal Bilimler Dergisi

A. ÇALIŞKUR, A. DEMIRHAN

Duyma/Hoşlanma, Algilanan Yeterlik, Çaba/Önem, Baski/Gerilim, Algılanan Seçme Hakkı ve Değer/Fayda olmak üzere toplam 6 boyut içinde gösterilmektedir. Ölçekte; İlgi Duyma/Hoşlanma boyutunda 7 soru (S1,S2,S3,S4,S5,S6,S7), Algilanan Yeterlik boyutunda 6 soru (S8,S9,S10,S11,S12,S13), Çaba/Önem boyutunda 5 soru (S14,S15,S16,S17,S18), Bask1/Gerilim boyutunda 5 soru (S19,S20,S21,S22,S23), Alg1lanan Seçme Hakk1 boyutunda 7 soru (S24,S25,S26,S27,S28,S29,S30), Değer/Fayda boyutunda ise 4 soru (S31,S32,S33,S34) yer almaktadır.

Yapılan ilk faktör analizinde Kaiser-Meyer-Olkin değerinin 0.900 olarak ve Bartlett Küresellik Testi'nde ise p değeri 0.000 olarak elde edilmiştir. Faktör analizinde "Temel Bileşenler" yöntemi kullanılmıştır. Envanterin son halinde toplam 34 ifade olduğundan 34 tane temel bileşen elde edilmiştir. Ancak, özdeğeri 1'den büyük olan temel bileşenlerin seçilmesi ölçütüne dayanarak belirleme yapılmıştır. Böylece toplam açılama yüzdesi 69.812 olan 8 faktör elde edilmiştir. Faktör 1 kendi başına toplam varyansın \%31.631'ini, Faktör 2 \%8.495'ini, Faktör $3 \% 7.999$ 'unu, Faktör $4 \% 6.407$ 'sini, Faktör 5 \%4.783'ünü, Faktör 6 \%3.902'sini, Faktör 7 \%3.587'sini, Faktör 8 \%3.018'ini açıklamaktadır. Faktör Analizi'ne bağlı Kaiser-Meyer-Olkin ve Bartlett Küresellik Testi sonuçları Tablo 4'te gösterilmektedir.

Tablo 4: IGGE'nin Yapı Geçerliği İçin Elde Edilen KMO ve Bartlett Testi Sonuçları

\begin{tabular}{lll}
\hline KMO Ölç̧ӗi & 0.900 & \\
Bartlett Ölçeği & 6781.811 & 0.000 \\
\hline
\end{tabular}

Kaiser-Meyer-Olkin (KMO) Örnekleme Yeterliliği ölçüsü, değişkenler arası korelasyonların faktör analizine uygunluğunu test etmektedir. Kaiser-Meyer-Olkin değerinin 0.50 değerinin üzerinde olması gerekmektedir (Field, 2000). Buna göre yapılan analiz sonucunda $\mathrm{KMO}=0.900$ olduğundan değişkenlerin faktör analizine uygunluğunun en üst seviyede olduğu görülmektedir.

Bartlett Küresellik Testi, değişkenler arasında yeterli oranda ilişki olup olmadığını göstermektedir (Fair, Black, Babin ve Anderson, 2010). Bartlett Küresellik Testi'nde $p<0.05$ 'ten düşük olmalıdır (Sipahi, Yurtkoru ve Çinko, 2006). Bu araştırmada $\mathrm{p}=0.000$ olduğundan değişkenler arasında faktör analizi yapılabilmesi için yeterli düzeyde bir ilişki olduğu söylenebilir. Böylece bu araştırmada ele alınan değişkenlerin faktör analizi yapmaya uygun olduğu ve araştırma 
verilerinin farklı istatistiksel analizler için elverişlilik derecesinin yüksek olduğu görülmektedir.

Faktör analizinde "Temel Bileşenler" yöntemi kullanılmıştır. Envanterin son halinde toplam 34 ifade olduğundan 34 tane temel bileşen elde edilmiştir. Ancak, özdeğeri 1'den büyük olan temel bileşenlerin seçilmesi ölçütüne dayanarak belirleme yapılmıştır. Böylece toplam açıklama yüzdesi 69.812 olan 8 faktör elde edilmiştir. Faktör 1 kendi başına toplam varyansın \%31.631'ini, Faktör 2 \%8.495'ini, Faktör 3 \%7.999'unu, Faktör 4 \%2. 6.407'sini, Faktör 5 \%4.783'ünü, Faktör $6 \% 3.902$ 'sini, Faktör $7 \% 3.587$ 'sini, Faktör 8 \%3.018'ini açılamaktadır. Faktör analizinde kavramsal anlamlılığın daha iyi olup olamayacağını araştırmak amacıyla rotasyon yöntemlerinden Varimax Yöntemi uygulandığında, faktörlerin kavramsal anlamlılığında artma görüldügüünden yorumlarda Varimax Yöntemi sonuçları kullanılmıştır. Buna göre, Varimax Rotasyon Yöntemi'ne göre orijinal ölçekten farklı olarak altı boyutun dışında Faktör 6 ve Faktör 8 olarak iki farklı boyutun daha oluştuğu görülmektedir. Faktör 6, "İlgi Duyma/Hoşlanma" faktöründen ayrılan S3, S4 ile "Algılanan Yeterlik" faktöründen ayrılan S13 ifadelerinin oluşturduğu bir faktördür. Aynı şekilde Faktör 8, S19 ile S24'ün kendi boyutlarından ayrılmaları sonucunda oluşan yeni bir faktördür.

Faktör analizi sonrasında her bir alt boyutun (faktörün) güvenirliği de hesaplanmıştır. $\mathrm{Bu}$ amaçla güvenirliğin belirlenmesinde Alpha modeli kullanılmıştır. Cronbach Alpha değeri faktör altındaki soruların toplamdaki güvenirlik seviyesini göstermektedir. Cronbach Alpha değeri faktör altındaki soruların toplamdaki güvenirlik seviyesini göstermektedir. Bu değerin 0.60 ve üstü olduğu durumlarda ölçeğin güvenilir olduğu kabul edilir (Sipahi, Yurtkoru ve Çinko, 2006). Tüm ölçeğin ve alt boyutların ayrı ayrı Cronbach Alpha değerleri Tablo 5'te görülmektedir:

Tablo 5 : Tüm Ölçeğin (34 Ifade) ve Faktörlerin Cronbach Alpha Değerleri

\begin{tabular}{lcc}
\hline Faktörler & $\begin{array}{c}\text { Faktör } \\
\text { Madde } \\
\text { Sayısı }\end{array}$ & $\begin{array}{c}\text { Cronbach Alpha } \\
\text { Değeri }\end{array}$ \\
\hline Faktör1: (İlgi Duyma/Hoşlanma) & 5 & 0.9151 \\
Faktör 2: (Algılanan Yeterlik) & 5 & 0.8650 \\
Faktör 3: (Değer/Fayda) & 6 & 0.6798 \\
Faktör 4: (Algılanan Seçme & 4 & 0.8223
\end{tabular}

Hakk1) 


\begin{tabular}{lcc} 
Faktör 5: (Çaba/Önem) & 5 & 0.8004 \\
Faktör 6: & 3 & 0.7672 \\
Faktör 7: (Baskı/Gerilim) & 4 & 0.7320 \\
Faktör 8: & 2 & 0.4278 \\
Genel Ölçek & 34 & 0.8675 \\
\hline
\end{tabular}

Faktör analizinde ortaya çıkan yeni boyutlarla ilgili olarak, Faktör 8'in Cronbach Alpha değeri incelendiğinde 0.60'ın altında olduğu görülmüş, güvenirlik değeri düşük olan bu faktörü oluşturan iki soru (S19 ve S24) analizden tamamen çıkarılarak faktör analizi ve Cronbach Alpha değerleri yeniden hesaplanmıştır. Cronbach Alpha değeri düşük olan, S19 ve S24 numaralı ifadelerin oluşturduğu Faktör 8 analizden çıkarılmasıyla, 32 ifade esas alınarak yeniden yapılan Faktör analizi sonuçları Tablo 6' da bulunmaktadır:

Tablo 6: Kaiser-Meyer-Olkin Ölçümü(KMO) ve Bartlett Testi Sonuçları

\begin{tabular}{lll}
\hline KMO Ölç̧ӗi & 0.903 & \\
Bartlett Ölçeği & 6568.435 & 0.000 \\
\hline
\end{tabular}

Yapılan yeni analiz sonucunda KMO değeri 0.903 olarak bulunmuştur ve bu değer oldukça yeterli olarak değerlendirilmektedir. Buna göre değişkenlerin faktör analizine uygunluğunun oldukça üst düzeyde olduğu söylenebilir. Bartlett Testi sonucu ise $\mathrm{p}$ değeri 0.000 olarak bulunmuştur; Bartlett Testi değerinin yüksek istatistiksel anlamlılık taşıması, mevcut değişkenlerimizin faktör analizi yapmaya uygun olduğunu ve araştırma verilerinin farklı istatistiksel analizler için elverişlilik derecesinin oldukça yüksek olduğunu da göstermektedir.

İGE'den, güvenilirlik değerleri düşük olan S19 ve S24 ifadelerinin çıkarılarak 32 ifadeye göre yapılan analiz sonucunda özdeğeri 1'den büyük olan yedi faktörün oluştuğu ve bu faktörlerin toplam varyansın \% 69.217'sini açıladıkları görülmüştür. Elde edilen bu varyans açklama yüzdesi Tablo 7 'de görüldügü gibi yeterli düzeyde bulunmuştur.

Tablo 7: IGGE'nin 32 İfade Üzerinden Yapılan Faktör Analizi Sonuçları

\begin{tabular}{cccc}
\hline Faktörler & Özdeğer(Eigenvalue) & $\begin{array}{c}\text { Varyans } \\
\text { Yüzdesi }\end{array}$ & $\begin{array}{c}\text { Kümülatif } \\
\text { Varyans } \\
\text { Yüzdesi }\end{array}$ \\
\hline 1 & 10.550 & 32.976 & 32.976 \\
2 & 2.885 & 9.011 & 41.987
\end{tabular}


Uşak Üniversitesi Sosyal Bilimler Dergisi $2013,6 / 4$

A. ÇALIŞKUR, A. DEMIRHAN

\begin{tabular}{llll}
\hline & & & \\
3 & 2.662 & 8.312 & 50.299 \\
4 & 2.081 & 6.504 & 56.803 \\
5 & 1.624 & 5.075 & 61.878 \\
6 & 1.188 & 3.701 & 65.579 \\
7 & 1.169 & 3.638 & 69.217 \\
\hline
\end{tabular}

32 maddelik ölçeğin ve alt boyutların ayrı ayrı Cronbach Alpha değerleri Tablo 8'de görülmektedir:

Tablo 8: İGE'nin Yapı Geçerliği İçin Yapılan Faktör Analizi Sonucunda Elde Edilen Faktörlere Göre Madde Dağılımları ve Faktör Yükleri

\begin{tabular}{|c|c|c|c|}
\hline Faktör & Madde & $\begin{array}{l}\text { Faktör } \\
\text { Yükü }\end{array}$ & $\begin{array}{c}\text { Faktörün } \\
\text { Açıklayıcılığ } 1 \text { (\%) }\end{array}$ \\
\hline \multirow{5}{*}{$\begin{array}{c}\text { Faktör 1 } \\
\text { (İlgi Duyma/Hoşlanma) }\end{array}$} & S1 & .773 & 32.976 \\
\hline & S2 & .780 & \\
\hline & S5 & .672 & \\
\hline & S6 & .834 & \\
\hline & S7 & .834 & \\
\hline \multirow{5}{*}{$\begin{array}{c}\text { Faktör } 2 \\
\text { (Algılanan Yeterlik) }\end{array}$} & S8 & .711 & 9.011 \\
\hline & S9 & .756 & \\
\hline & S10 & .777 & \\
\hline & S11 & .782 & \\
\hline & $\mathrm{S} 12$ & .798 & \\
\hline \multirow{4}{*}{$\begin{array}{c}\text { Faktör } 3 \\
\text { (Algılanan Seçme } \\
\text { Hakkı) }\end{array}$} & S25 & .671 & 8.312 \\
\hline & S26 & .754 & \\
\hline & S28 & .762 & \\
\hline & S29 & .635 & \\
\hline \multirow{6}{*}{$\begin{array}{c}\text { Faktör } 4 \\
\text { (Değer/Fayda) }\end{array}$} & S27 & -.727 & 6.504 \\
\hline & S30 & -.650 & \\
\hline & S31 & .535 & \\
\hline & S32 & .527 & \\
\hline & S33 & .610 & \\
\hline & S34 & .622 & \\
\hline \multirow{5}{*}{$\begin{array}{c}\text { Faktör } 5 \\
\text { (Çaba/Önem) }\end{array}$} & S14 & .785 & 5.075 \\
\hline & S15 & .690 & \\
\hline & S16 & .815 & \\
\hline & S17 & .575 & \\
\hline & $\mathrm{S} 18$ & .679 & \\
\hline \multirow{2}{*}{$\begin{array}{r}\text { Faktör } 6 \\
\text { (İş Algısı) }\end{array}$} & S3 & .685 & 3.638 \\
\hline & S4 & .691 & \\
\hline
\end{tabular}


Uşak Üniversitesi Sosyal Bilimler Dergisi

$2013,6 / 4$

A. ÇALIŞKUR, A. DEMIRHAN

\begin{tabular}{cccc}
\hline & S13 & .653 & \\
\hline Faktör 7 & S20 & .784 & 3.701 \\
(Bask1/Gerilim) & S21 & .564 & \\
& S22 & .790 & \\
& S23 & .603 & \\
\hline
\end{tabular}

İGE'nin yapı geçerliğini belirlemek için yapılan faktör analizi sonuçları Varimax Rotasyonu ile hesaplanmıştır. S3, S4 ve S13'ten oluşan yeni faktöre "İş Algısı" adı verilmiştir.

İGE'nin geçerlik çalışmasında ikinci adım, ölçeğin yine yapı geçerliğinin bir başka boyutunu (iç tutarlılığını) belirlemektir. Bu amaçla ölçeğin genelinin Cronbach Alpha değeri hesaplanmış; Cronbach Alpha değeri 0.8694 olarak bulunmuştur. Alt ölçeklerin Cronbach Alpha değerleri ise sırasıyla; "İlgi Duyma/Hoşlanma" boyutu için 0.9152,"Algılanan Yeterlik" boyutu için 0.8650, "Algılanan Seçme Hakkı" boyutu için 0.8223, "Değer/Fayda" boyutu için 0.6798, "Çaba/Önem" boyutu için 0.8004, "Baskı/Gerilim" boyutu için 0.7320 ve "İş Algısı" boyutunun ise 0.7664 olarak hesaplanmıştır. Elde edilen sonuçlar, Tablo 9'da görüldüğü gibi, ölçeği oluşturan ifadelerin yapı geçerliği (iç tutarlılı̆̆ının) olduğunu göstermektedir.

Tablo 9: IGGE'nin Genel Ölçek ve Faktörlerinin Cronbach Alpha Değerleri

\begin{tabular}{lcc}
\hline Faktörler & $\begin{array}{c}\text { Faktör Madde } \\
\text { Sayısı }\end{array}$ & $\begin{array}{c}\text { Cronbach } \\
\text { Alpha } \\
\text { Değeri }\end{array}$ \\
\hline Faktör 1: (İlgi Duyma/Hoşlanma) & 5 & 0.9152 \\
Faktör 2: (Algılanan Yeterlik) & 5 & 0.8650 \\
Faktör 3: (Algılanan Seçme & 4 & 0.8223 \\
Hakkı) & & \\
Faktör 4: (Değer/Fayda) & 6 & 0.6798 \\
Faktör 5: (Çaba/Önem) & 5 & 0.8004 \\
Faktör 6: (İş̧Algısı) & 3 & 0.7664 \\
Faktör 7: (Baskı/Gerilim) & 4 & 0.7320 \\
Genel Ölçek & 32 & \\
\hline
\end{tabular}

Ayrıca envanterin yapı geçerliğine (iç tutarlılık boyutu) yönelik diğer bir inceleme de Pearson Korelasyon Analizi ile yapılmıştır. İçsel Güdülenme Ölçeği toplam puanı ile her alt ölçekten elde edilen puanların ilişki katsayıları Tablo 10 'da gösterilmiştir. İGE 
Uşak Üniversitesi Sosyal Bilimler Dergisi

$2013,6 / 4$

A. ÇALIŞKUR, A. DEMIRHAN

alt ölçek ile toplam puanı puanlarının ilişki katsayılarının $\mathrm{r}=0.602$ 0.792 arasında değiştiği görülmektedir. Alt ölçek puanları, toplam puanla pozitif yönde ilişki bulunmaktadır.

Tablo 10: İGE'nin Alt Ölçek ve Toplam Puanlar Arasındaki Korelasyon Değerleri

\begin{tabular}{lccc}
\hline Madde & $\mathrm{n}$ & Korelasyon(r) & Anlamlılık(p) \\
\hline İlgi Duyma/Hoşlanma & 320 & 0.792 & 0.000 \\
Algılanan Yeterlik & 320 & 0.602 & 0.000 \\
Algılanan Seçme Hakkı & 320 & 0.699 & 0.000 \\
Değer/Fayda & 320 & 0.760 & 0.000 \\
Çaba/Önem & 320 & 0.697 & 0.000 \\
İş Algısı & 320 & 0.629 & 0.000 \\
Baskı/Gerilim & 320 & 0.671 & 0.002 \\
\hline
\end{tabular}

Araştırmanın geçerlik çalışmasında son adım, İGE'nin ölçüt geçerliğinin belirlenmesidir. Bu amaçla 40 kişiye İGE ile Mottaz'ın (1985) geliştirdiği Dündar ve arkadaşları (2007) tarafından gözden geçirilerek hazırlandığı 9 maddeden oluşan "İçsel Motivasyon Anketi" (IMA) uygulanmıştır. Araştırmada kullanılan envanterin ölçüt geçerliğinde yararlanılan İMA, Ağca ve Ertan'ın (2008) yürüttüğü "Duygusal Bağlılık İçsel Motivasyon İlişkisi" adlı araştırmada kullanılmıştır. İki farklı ölçeğin arasında anlamlı bir korelasyonu belirleyebilmek için Pearson Korelasyon Yöntemi'nden yararlanılmıştır. Yapılan analiz sonucunda bu iki ölçek arasında 0.679 değeri elde edildiğinden 0.01 anlamlılık düzeyinde bir korelasyon olduğu belirlenmiştir. Yapılan analizler sonucunda İGE'nin ölçüt geçerliğini sağladığı görülmüştür (Bakınız Tablo 11).

Tablo 11: IGE ile IMA Arasındaki Korelasyon Analizi Sonuçları

\begin{tabular}{llcc}
\hline & & İGE & İMA \\
\hline İGE & Pearson & 1 & $0.679\left(^{* *}\right)$ \\
& Korelasyon & & 0.000 \\
& Anlamll1k $(\mathrm{p})$ &. & 40 \\
$\mathrm{~N}$ & 40 & 1 \\
İMA & Pearson & $0.679\left(^{* *}\right)$ & \\
& Korelasyon & 0.000 &. \\
& Anlamlllk $(\mathrm{p})$ & 40 & 40 \\
\hline
\end{tabular}




\section{Tartışma ve Sonuç}

İGE'nin Türkiye'de uygulanabilmesi amaciyla dilsel eşdeğerlik, güvenirlik ve geçerlik çalışması yapılmıştır. Çalışmada ilk aşama, envanterin dilsel eşdeğerlik çalışması olarak belirlenmiş ve uzman bir ekiple orijinal ölçek metni üzerinde çift yönlü çeviriler ve kontrollerle bu aşama tamamlanmıştır. İkinci aşamada ise envanterin güvenirlik ve geçerlik çalışmaları yapılmıştır. İGE'nin Türkiye güvenirlik çalışmasında, toplanan veriler üzerinde yapılan istatistiksel analiz sonuçlarına göre, test-tekrar test güvenirlik değeri p $>0.05$ olarak elde edilerek ölçeğin iki farklı zamanda uygulanması arasında anlamlı bir farklılık bulunmadığ 1 ve ölçeğin test-tekrar test güvenirliğinin olduğunu göstermiştir. "Test-tekrar test yöntemi, bir testin aynı gruba belli aralıklarla iki kez uygulanmasıla elde edilen puanlar arasındaki korelasyon ile açılanır" (Büyüköztürk, 2011). Bu sonuçlara göre İGE güvenilir biçimde uygulanabilir.

Envanterin geçerlik çalışmasında ise faktör analizi, iç tutarlılık ve ölçüt geçerliği ölçülmüştür. Faktör Analizi önce orijinal ölçekte olduğu gibi 34 madde üzerinden yapılmıştır. Ancak envanterin orijinalinde bulunmayan ama yeni bir faktör grubu olarak görünen Faktör 6 ve Faktör 8 belirlenmiş; Faktör 8'in Cronbach Alpha değeri 0.60 'ın altında olduğundan envanterde ayrı bir faktör olarak bulunması uygun görülmemiştir. Faktör 6 ise, orijinal ölçekte bulunmayan "İş algısı" faktörü olarak adlandırılmıştır. Bu durumda Faktör Analizi 7 faktör üzerinden tekrar yapılmış ve anlamlı sonuçlar elde edilmiştir. Ölçeğin orijinalinin faktör analizinde ise, 4 temel faktör grubuna (İlgi Duyma/Hoşlanma, Algılanan Yeterlik, Çaba/Önem, Bask1/Gerilim) karşılık gelen 18 madde belirlenmiştir. 4 faktör grubuna dağılan ölçeğin 18 maddelik ve 16 maddelik versiyonları karşılaştırılmış ve orta düzeyde ilişkili bulunmuştur. Ayrıca bu iki ayrı versiyonun Ki-Kare değerleri ölçeğin $p<0.05$ düzeyinde anlamlı olduğunu ve ölçeğin geçerli olduğunu göstermektedir. $\mathrm{Bu}$ durumda faktör analizinin Türkiye'de orijinalinden daha kapsamlı bir biçimde ele alındığı görülmektedir.

IGG'nin yapı geçerliğinin bir başka boyutu olan iç tutarlılık analizinde, ölçeğin alt ölçek ve toplamı arasındaki korelasyon analizleri (Cronbach Alpha ve Pearson) pozitif yönde anlamlı ilişki göstermiştir. Analizlerde, ölçeğin geneli için Cronbach Alpha $(\alpha=0.8694)$ ve Pearson korelasyonu $\mathrm{p}<0.01$ olarak bulunmuştur. Alt ölçeklerin $\alpha$ değerleri ise sırasıyla; "İlgi Duyma/Hoşlanma" boyutu için 0.9152,“Algılanan Yeterlik" boyutu için 0.8650, "Algılanan Seçme 
Hakk1" boyutu için 0.8223, "Değer/Fayda" boyutu için 0.6798, "Çaba/Önem" boyutu için 0.8004, "Baskı/Gerilim" boyutu için 0.7320 ve "İş Algisı" boyutunun ise 0.7664 olarak elde edilmiştir. Orijinal ölçeğin (IMI)'nin ise güvenirlik ve geçerlik çalışması McAuley, Duncan ve Tammen tarafından yapılmıştır ve ölçeğin güvenirlik katsayısı alt ölçeklere göre $\alpha=0.68$ ile 0.84 arasındadır; ölçeğin genelinin iç tutarlık katsayısı ise $\alpha=0.85^{\prime}$ tir. Bu sonuçlara göre ölçeğin orijinali ile Türkiye analiz sonuçları birbirine oldukça yakındır. Genel olarak, madde-toplam korelasyonu 0.30 ve daha yüksek olan maddelerin bireyleri iyi ayırt ettiği söylenebilir. (Büyüköztürk, 2011).

Geçerlik çalışmasının son aşamasında ölçüt geçerliği incelenmiş ve Mottaz'ın (1985) geliştirdiği Dündar ve arkadaşları (2007) tarafından gözden geçirilerek hazırlandığ 19 maddeden oluşan "İçsel Motivasyon Anketi" ile "İGE" arasında anlamlı bir ilişki olduğu saptanmıştır.

İGE'nin dilsel eşdeğerlik, güvenirlik ve geçerlilik çalışmalarının ayrıntılı olarak yapılmasının sonucunda, İGE'nin Türkiye koşullarında 18 ile 29 yaş arası kişilere uygulanabilecek güvenilir ve geçerli bir ölçek olduğunu göstermektedir

\section{Kaynakça}

Ağca V. ve Ertan H. (2008). Duygusal bağlılık içsel motivasyon ilişkisi: Antalya'da beş yıldızlı otellerde bir inceleme, Afyon Kocatepe Üniversitesi İ.I.B.F. Dergisi, 10(2), 135-156.

Amabile, T., Hill, K.G., Hennesey, B.A., Tighe, E.M. (1994). The work preference inventory: Assesing intrinsic and extrinsic motivational orientations. Journal of Personality and Social Psychology, 66(5), 950967.

Amorose, A.J.(2001). Pre- to Post-Season Changes in the intrinsic motivation of first year college athletes. Journal of Applied Sport Psychology, 13, 355-373.

Büyüköztürk, Ş. (2011). Sosyal Bilimler İçin Veri Analizi El Kitabı. Ankara: Pegem Akademi.

Deci, E.L. ve Ryan, R.M. (1985). Intrinsic motivation and selfdetermination in human behaviour. New York: Plenum Press. 
Deci, E.L. ve Ryan, R.M. (1991). A motivation aprroach to self. R.A. Dienstbier (Eds.), Perspectives on Motivation, Nebraska Symposium (s.237-289). Nebraska: University of Nebraska Press.

Dündar, S. Özutku, H. Ve Taşpınar, F. (2007). İçsel ve dışsal motivasyon araçlarının işgörenlerin motivasyonu üzerindeki etkisi: Ampirik bir inceleme. Gazi Üniversitesi Ticaret ve Turizm Ĕ̆itim Fakültesi Dergisi, 2, 105-119.

Hair, J.F., Black, W.C., Babin, B.J., Anderson R.E.(2010). Multivariate Data Analysis:A Global Perspective. N.J: Pearson Prentice Hall.

Field, A. (2000). Discovering Statistics Using SPSS for Windows. London: Sage Publications.

Franco, L.M., Bennett, S. ve Kanfer, R. (2002). Health sector reform and public sector health sector worker motivation: A conceptual framework, Social Science and Medicine. 54, 1255-1266.

Gagné, M., Forest, J., Gilbert, M.H., Aube. C., Morin E., Malorni, A. (2008). The motivation at work scale: Validation in two languages. ASAX, (157-176).

Guay, F., Vallerand, R.J., Blanchard, C. (2000). On the assesment of situational intrinsic and extrinsic motivation: The situational motivation scale. Motivation and Emotion, 24(3),175-213.

Guay, F., Mageau, G., \& Vallerand, R.J. (2003). On the hierarchical structure of self-determined motivation : A test of top-down and bottom-up effects. Personality and Social Psychology Bulletin, 29, 992-1004.

Harlow, H. F., Harlow, M. K., \& Meyer, D. R. (1950). Learning motivated by a manipulation drive. Journal of Experimental Psychology, 40(2), 228-234.

Huddlestone, H., Fry, M., Brown, T.C. (2012). Corporate fitness members' perceptions of the enviroment and their intrinsic motivation. Journal of Experimental Psychology, 21(1), 15-23.

Hull, C.L. (1943). Principles of Behaviour. New York: Appleton Century Crofts. 
Uşak Üniversitesi Sosyal Bilimler Dergisi

A. ÇALIŞKUR, A. DEMIRHAN

Karatepe, O.M. ve Uludağ, O. (2007). Conflict, exhaustion and motivation: A study of frontline employees in Northern Cyprus Hotels, Hospitality Management. 26, 645-665.

Koçel, T. (2007). İşletme Yöneticiliği. İstanbul: Arıkan Basım Yayın Dağıtım.

Kuruüzüm, A. , Irmak, S. ve Çetin, E.İ. (2010). Ahmet Yesevi Üniversitesi Türk Dünyası Sosyal Bilimler Dergisi, 53, 183-198.

Mayo, R.J. (1976). The development and construct validation of a measure of intrinsic motivation. Unpublished doctoral dissertation, Purdue University.

McAuley, E., Duncan, T. ve Tammen, V.V. (1989). Psychometric properties of the intrinsic motivation inventory in a competetive sport setting. Research Quarterly for Exercise and Sport, 60(1), 48-58.

Mccullagh, P. (2005). Sport and Exercise Psychology Lecture. Cal State University.

Mitchell, T. R. (1997). Matching motivational strategies with organizational context. Research in Organizational Behavior, 19, 57149.

Mottaz, C.J. (1985). The relative importance of intrinsic and extrinsic rewards as determinants of work satisfaction, Sociological Quartely, 26(3), 365-385.

Murcia, J.A.M., Gimeno, E.C., Carretero, C.M., Lacarcel, J.A.V., Calvo, T.M. (2012). Social goals, basic psychological needs and intrinsic motivation as predictors of the perception of effort in physical education. Revista de Psicologia del Deporte, 21 (2), 215-221.

Murray, H.A. (1938). Explorations in Personality.. New York: Oxford University Press.

Nelson, D.L. ve Quick, J.C. (2000). Organizational Behaviour Foundations, Realities and Clallenges. Ohio: South Western. 
Olusola, O.(2011). Intrinsic motivation, job satisfaction, and selfefficacy as predictors of job performance of industiral workers in Ijebu zone on Ogun State. Uluslar arası Sosyal araştırmalar Dergisi, $4(17), 569-577$.

Orhunbilge, N. (2000). Örnekleme Yöntemleri ve Hipotez Testleri, İstanbul: Avcıol Basım Yayın.

Özmen, A. (2013). Örnekleme ve örnekleme dağılımları. E. Şıklar, ve A. Özdemir (Edi.), İstatistik-II (s.14). Eskişehir: T.C. Eskişehir Anadolu Üniversitesi Yayını.

Pinder, C.C. (1998). Work motivation in organizational behaviour. Upper Saddle River, NJ: Prentice Hall.

Ryan, M. ve Deci, E.L. (2000). Intrinsic and Extrinsic Motivations: Classic Definitions and New Directions. Contemporary Educational Psychology, 25, 54-67.

Sipahi, B., Yurtkoru, E.S. ve Çinko, M. (2006). Sosyal Bilimlerde SPSS'le Veri Analizi, İstanbul: Beta Yayınevi.

Skinner, B.F. (1953). Science and Human Behaviour. New York: Mc millan.

Thomas, K. (2000). Intrinsic motivation and how it works. Training, 37, 130-135.

Viira, R. ve Koka, A. (2012). Participation in afterschool sport. Kinesiology, 44(2), 199-208.

White, R.W. (1959). Motivation reconsidered. Psychological Review, 66, 297-333.

Wilson, J. (2005). Hull's Quantitative Equation on Human Performance. Journal of Hyperlasia Research, 5(2), 1-4.

Yıldız, Z. Ayhan, S., Erdoğmuş, S. (2009).The impact of nurses' motivation to work, job satisfaction and sociodemographic characteristics on intention to quit their job: An empirical study in Turkey.Applied Nursing Research, 22, 113-118. 